\title{
Performance of 'Orlando' Tangelo Trees on Ten Rootstocks in Arizona
}

\author{
Esmaeil Fallahi ${ }^{1}$ and Zahra Mousavi ${ }^{1}$ \\ Southwest Idaho Research and Extension Center, University of Idaho, 29603 U of I Lane, Parma, \\ ID 83660
}

\author{
D. Ross Rodney ${ }^{1}$ \\ Yuma Agricultural Center, University of Arizona, Route 1 Box 40-M Somerton, AZ 85350 \\ Additional index words. Citrus paradisi $\times$ C. reticulata
}

\begin{abstract}
The influence, of 10 rootstocks on growth, yield, and fruit quality of 'Orlando' tangelo (Citrus paradisi Macf. $\times$ C. reticulata Blanco) was studied for 7 years under the arid climate of southwestern Arizona. Trees on macrophylla (Alemow) (C. macrophylla Wester) were the most precocious and produced the highest yields 4 years after planting. Seven-year cumulative yields of trees on Carrizo citrange $[C$. sinensis $(L$.) Osbeck $\times$ Poncirus trifoliata (L.) Raf.], Yuma citrange ( $P$. trifoliata $\times C$. sinensis), Volkamer lemon $(C$. limon Burm f.), rough lemon $(C$. jambhiri Lush), Taiwanica $(C$. taiwanica), and macrophylla were similar and higher than those on Savage citrange $(P$. trifofiata $\times C$. sinensis), Batangas mandarin (C. reticulata Blanco), Ichang pummelo (C. ichangensis hyb.), and Palestine sweet lime ( $C$. limettoides Tan.). Trees on Carrizo citrange had relatively large tree canopies and larger fruit, and fruit from trees on Volkamer lemon and rough lemon was lower in total soluble solids concentration (TSS) and total acids (TA) than fruit from trees on other rootstocks. Fruit from trees on Savage citrange was smallest but had the highest TSS. Considering yield, growth, and/or various quality factors, Volkamer lemon, rough lemon, Yuma citrange, and particularly Carrizo citrange, are suitable for 'Orlando' tangelo in the arid regions of the southwestern United States. Trees on macrophylla, Savage citrange, and Ichang pummelo had small canopies and were least productive. 'Orlando' tangelo trees on Savage citrange and Ichang pummelo rootstocks, however, might be good choices at a spacing closer than $7 \times 7 \mathrm{~m}$ because of their high fruit TSS and fruit size, respectively. Trees on Palestine sweet lime declined and had low yields, and those on Batangas mandarin had low yields and poor fruit quality. These rootstocks are not recommended for 'Orlando' tangelo under conditions similar to those of this experiment.
\end{abstract}

Effects of rootstock on yield and fruit quality have been reported for various citrus cultivars (Castle,. 1986, 1987; Castle and Phillips, 1977; Cooper and Bruce, 1950; Fallahi et al., 1989; Gardner and Horanic, 1966; Hilgeman et al., 1966; Hutchison and Hearn, 1977; Krezdorn, 1977; Krezdorn and Phillips, 1970; Rouse and Maxwell, 1979; Wutscher, 1977, 1979; Wutscher and Dube, 1977; Wutscher and Shull, 1972, 1973, 1975, 1976). Hutchison and Hearn (1977) studied yield and fruit quality of 'Nova' [(C. reticulata Blanco $) \times(C$. paradisi macf. $\times C$. reticulata)] and 'Orlando' tangelos on various rootstocks in Florida. 'Nova' and 'Orlando' tangelo trees on Troyer citrange, Carrizo citrange, and Cleopatra mandarin had higher yields of high-quality fruit than trees on other rootstocks. 'Nova' and 'Orlando' trees on rough lemon were most productive and produced the largest canopy, and fruit from these trees had the lowest total soluble solids concentration (TSS) and juice content. Fruit from 'Orlando' trees on Rusk citrange and 'Nova' trees on sour orange had the highest TSS (Hutchison and Hearn, 1977). Wutscher and Shull (1976) studied the performance of 'Orlando' tangelo on 16 rootstocks in Texas and reported that the trees on Swingle citrumelo, Morton citrange, Rangpur lime, and Cleopatra mandarin had higher yield than trees on other rootstocks when the trees were 3 to 10 years old. 'Orlando' tangelo fruit quality was superior on Sun Chu Sha mandarin, Keraji mandarin, Kinokuni mandarin, sour orange, and Morton citrange. In a trial with 11 rootstocks in Florida, 'Orlando' tangelo trees on sweet lime had the highest cumulative yield, while

Received for publication 13 Oct. 1989. Publications no. 7172 from the Arizona Agricultural Experiment Station. The cost of publishing this paper was defrayed in part by the payment of page charges. Under postal regulations, this paper therefore must be hereby marked advertisement solely to indicate this fact. ${ }^{1}$ Horticulturist. those on trifoliate orange had the lowest yield (Krezdorn and Phillips, 1970).

Arizona produced a total of $126,000 \mathrm{t}$ of tangerines and tangelos from 1700 ha between 1983 and 1988 (Arizona Agricultural Statistics Service, 1988). However, there have been no comprehensive long-term studies in Arizona evaluating performance of 'Orlando' tangelo on various rootstocks. Our objective was to evaluate the effects of 10 rootstocks on yield, growth, and fruit quality of 'Orlando' tangelo grown in Arizona. The rootstocks evaluated and climatic conditions in this experiment were different from those of other reports (Krezdorn, 1977; Krezdorn and Phillips, 1970; Wutscher and Shull, 1976). This long-term study enables us to identify potential rootstocks for the arid regions of the southwestern United States.

\section{Materials and Methods}

'Orlando' tangelo was budded on 10 rootstocks. Trees were grown in containers in the greenhouse and planted in the field in Mar. 1970. The 10 rootstocks were: Carrizo citrange, Yuma citrange, Volkamer lemon, rough lemon, Taiwanica, macrophylla, Savage citrange, Batangas mandarin, Ichang pummelo, and Palestine sweet lime. The budwood sources and budded trees were indexed and were free of viruses. Tree spacing was $7 \times 7 \mathrm{~m}$, the soil was a well-drained deep sand, with the top $20 \mathrm{~cm}$ mixed with silt classified as Superstition sand (Typic Calciorthid, $80 \%$ sand), and the soil $\mathrm{pH}$ was 8.0 due to high $\mathrm{Na}$ and $\mathrm{Ca}$ content. 'Fairchild' tangerine [(C. reticulata Blanco) $\times(C$. paradisi Macf.)] planted around the experimental block served as the pollenizer for 'Orlando'.

Ammonium nitrate was applied in four equal applications in October, December, February, and April every year at an annual rate of 0.5 to $1.5 \mathrm{~kg} \mathrm{~N} /$ tree, depending on tree age. Trees were flood-irrigated biweekly between April and September and monthly 
from October to March. Pesticide was applied twice annually for thrips control, and the orchard was disked when needed for weed control. Overall, tree spacing and cultural practices in the experimental block were similar to those in commercial groves.

The experimental design was a randomized complete block with four blocks (replications) and two trees per plot. Fruit from each tree was harvested into boxes that hold $30 \mathrm{~kg}$, and yield was recorded in 1974 (4 years after planting) for precocity evaluation and then annually from 1982 through 1988. Cumulative yields were calculated for the years 1982 through 1988 (7-year cumulative yield). Trunk diameter was measured and trunk crosssectional-area was calculated in 1974 and 1988 (4 and 18 years after planting, respectively). Tree volume was calculated using measurements of tree height and width: $\mathrm{V}=0.524 \times$ height $\times$ width $^{2}$ (Turrell, 1961).

Fruit weight, juice volume (total juice per fruit), percent juice content (percent by fruit weight), TSS, total titratable acid (TA), TSS : TA ratio, and rind thickness were evaluated annually for 7 years. Fifteen fruit per tree (30 fruit per plot) were collected randomly in early December of each year. Fruit were weighed, cut in half, and rind thickness was measured. Juice was extracted by pushing each half of the fruit against the rotating blades of an electric juicer until only rind remained. The juice was passed through a strainer to remove the pulp and to extract pure juice, Total juice volume per fruit was measured in a graduated cylinder. A 500-ml aliquot of each composite juice from all fruit of each sample was weighed, and percent juice content of each fruit was calculated. TSS was measured with a temperature-compensated refractometer (Atago N1). TA was determined by titration with $0.39 \mathrm{~N} \mathrm{NaOH}$ to a $\mathrm{pH}$ of 8.0, using an automated Fisher Titralizer (Model 41; Fisher Scientific Co., Pittsburgh) and TA was expressed as citric acid. Analyses of variance for yield in each individual year and for cumulative yield over 7 years, trunk cross-sectional area for 1974 and 1988, tree canopy volume for 1988, and analyses of variance for 7year averages for each quality factor are reported. Mean separations were computed with Duncan's multiple range test when a significant $\mathrm{F}$ value existed.

\section{Results and Discussion}

Yield and growth. The trees on the rootstocks are ranked in Table 1 according to 7-year cumulative yields. Trees on macro- phylla were precocious and produced significantly higher yield in 1974 (4 years after planting) than trees on all other rootstocks (Table 1). A similar result was obtained with 'Redblush' grapefruit on macrophylla (Fallahi et al., 1989). Yields of trees on macrophylla, however, were lower than those on Carrizo citrange, Taiwanica, Volkamer lemon, and Yuma citrange after 1982 (Table 1). Trees on macrophylla had either a similar or larger trunk cross-sectional area in 1974, but in 1988, these trees had smaller cross-sectional areas and canopy volumes than those on carrizo citrange, rough lemon, Taiwanica, Volkamer lemon, and Yuma citrange (Table 1). This slowing down in growth is responsible for the lower yields of trees on macrophylla after 1982. Growth of trees on Palestine sweet lime also slowed down severely, which reduced canopy volume, trunk cross-sectional area, and cumulative yield (Table 1). Reduction in the growth rate of trees on macrophylla and Palestine sweet lime could be due to sieve tube necrosis decline, as the visual symptoms of trees were similar to those of-sieve tube necrosis in lemons (Fallahi et al., 1990). The bark below the bud union of the declining trees was severely discolored and contained gum deposits. This contrasts with our previous study, where Palestine sweet lime was found to be among the high-yielding rootstocks for 'Redblush' grapefruit (Fallahi et al., 1989). After 1982, trees on Carrizo citrange, Yuma citrange, Volkamer lemon rough lemon, and Taiwanica were always in the high-yielding group (cumulative yield between 1052 to $828 \mathrm{~kg} /$ tree), while trees on Savage citrange, Batangas mandarin, Ichang pummelo, and Palestine sweet lime were in the low-yielding group (cumulative yield between 629 to $623 \mathrm{~kg} /$ tree) (Table 1). As in the present study (Table 1), 'Redblush' grapefruit on Volkamer, lemon, rough lemon, and Carrizo citrange was more productive than on Savage citrange and Ichang pummelo (Fallahi et al., 1989). Cumulative yields of trees on Carrizo citrange and rough lemon were similar (Table 1), in contrast to the 4-year cumulative yield of 'Orlando' tangelo trees on rough lemon in Florida, which was significantly higher than that on Carrizo citrange when the trees were between 5 to 8 years old (Krezdorn and Phillips, 1970). The yield differences could be due to the difference in evaluation periods (4 years vs. 7 years). Trees on rough lemon had larger cross-sectional areas than those on Carrizo citrange in Florida when measured 10 years after planting (Hutchison and Hearn, 1977). We also observed a similar re-

Table 1. Influence of rootstock on yield, cross-sectional area, and tree canopy volume of 'Orlando' tangelo. ${ }^{\mathrm{z}}$

\begin{tabular}{|c|c|c|c|c|c|c|c|c|c|c|c|c|}
\hline \multirow[b]{2}{*}{ Rootstock $^{y}$} & \multicolumn{8}{|c|}{ Yield per tree $(\mathrm{kg})$} & \multirow{2}{*}{$\begin{array}{c}\text { Cumulative } \\
\text { yield } \\
1982-88 \\
(\mathrm{~kg} / \text { tree })\end{array}$} & \multicolumn{2}{|c|}{$\begin{array}{c}\text { Trunk cross } \\
\text { section }\end{array}$} & \multirow{2}{*}{$\begin{array}{c}\text { Tree } \\
\text { canopy } \\
\text { volume, } 1988 \\
\left(M^{3}\right)\end{array}$} \\
\hline & 1974 & 1982 & 1983 & 1984 & 1985 & 1986 & 1987 & 1988 & & $\begin{array}{l}1974 \\
\left(\mathrm{~cm}^{2}\right)\end{array}$ & $\begin{array}{l}1988 \\
\left(\mathrm{~cm}^{2}\right)\end{array}$ & \\
\hline CAR & $34 \mathrm{de}$ & 103 a & $148 \mathrm{a}$ & $138 \mathrm{a}$ & $134 a b$ & 239 a & $127 a b$ & $114 \mathrm{a}$ & 1002 a & $48 \mathrm{~b}$ & $487 a b$ & $113 \mathrm{a}$ \\
\hline TAI & $37 \mathrm{~cd}$ & $75 a b c$ & $120 \mathrm{ab}$ & $134 \mathrm{a}$ & $160 \mathrm{a}$ & $241 \mathrm{a}$ & $129 a b$ & $111 \mathrm{a}$ & 969 a & $77 \mathrm{a}$ & $504 a b$ & $95 \mathrm{ab}$ \\
\hline RLE & $70 \mathrm{~b}$ & $83 a b c$ & $127 \mathrm{ab}$ & 141 a & $145 \mathrm{a}$ & 251 a & $105 \mathrm{bcd}$ & $107 \mathrm{a}$ & 959 a & $77 \mathrm{a}$ & $497 \mathrm{ab}$ & $90 \mathrm{abc}$ \\
\hline $\mathrm{BAT}$ & $20 \mathrm{c}$ & $49 \mathrm{c}$ & $92 \mathrm{bc}$ & $89 \mathrm{c}$ & $96 \mathrm{c}$ & $183 \mathrm{bc}$ & $111 \mathrm{bc}$ & $77 \mathrm{ab}$ & $694 \mathrm{~b}$ & $33 \mathrm{c}$ & $439 \mathrm{~b}$ & $69 \mathrm{bcd}$ \\
\hline SAV & $29 \mathrm{de}$ & $60 \mathrm{bc}$ & $85 \mathrm{bc}$ & $105 \mathrm{bc}$ & $87 \mathrm{c}$ & $167 \mathrm{c}$ & $110 \mathrm{bc}$ & $80 a b$ & $692 \mathrm{~b}$ & $36 \mathrm{bc}$ & $345 c$ & $63 \mathrm{~cd}$ \\
\hline ICH & $27 \mathrm{de}$ & $59 \mathrm{bc}$ & $72 \mathrm{c}$ & $104 \mathrm{bc}$ & $83 \mathrm{c}$ & $158 \mathrm{c}$ & $84 \mathrm{~cd}$ & $94 \mathrm{ab}$ & $653 \mathrm{~b}$ & $34 c$ & $345 \mathrm{c}$ & $53 \mathrm{~d}$ \\
\hline PAL & $51 \mathrm{c}$ & $60 \mathrm{bc}$ & $87 \mathrm{bc}$ & $99 \mathrm{bc}$ & $93 \mathrm{c}$ & $155 \mathrm{c}$ & $75 \mathrm{~d}$ & $54 \mathrm{~b}$ & $623 \mathrm{~b}$ & $75 \mathrm{a}$ & $315 \mathrm{c}$ & $41 \mathrm{~d}$ \\
\hline
\end{tabular}

${ }^{3}$ Each value represents the mean of four two-tree replications for each individual year. Mean separation within columns by Duncan's multiple range test, $P=0.05$.

${ }^{y}$ Abbreviations: $\mathrm{YUM}=$ Yuma citrange; $\mathrm{CAR}=$ Carrizo citrange; TAI $=C$. taiwanica $; \mathrm{RLE}=$ rough lemon; VOL $=\mathrm{Volkamer}$ lemon; $\mathrm{MAC}=$ C. macrophylla; $\mathrm{BAT}=$ Batangas mandarin; SAV = Savage citrange; $\mathrm{ICH}=$ Ichang pummelo; PAL = Palestine sweet lime. 
Table 2. Influence of rootstock on fruit quality of 'Orlando' tangelo.

\begin{tabular}{|c|c|c|c|c|c|c|c|}
\hline Rootstock & $\begin{array}{c}\text { Fruit wt } \\
(\mathrm{g}) \\
\end{array}$ & $\begin{array}{c}\text { Juice } \\
\text { content } \\
\text { (ml/fruit) }\end{array}$ & $\begin{array}{c}\text { Percent } \\
\text { juice } \\
(w / w) \\
\end{array}$ & $\begin{array}{c}\text { Peel } \\
\text { thickness } \\
(\mathrm{mm})\end{array}$ & $\begin{array}{c}\text { Total soluble } \\
\text { solids (TSS) } \\
(\%)\end{array}$ & $\begin{array}{c}\text { Total } \\
\text { acids (TA) } \\
(\%)\end{array}$ & $\begin{array}{c}\text { TSS : TA } \\
\text { ratio }\end{array}$ \\
\hline YUM & $137 a b c$ & $69.7 \mathrm{bc}$ & $52.1 \mathrm{ab}$ & $3.07 \mathrm{bcd}$ & $11.9 \mathrm{~b}$ & $0.91 \mathrm{bc}$ & $13.2 \mathrm{ab}$ \\
\hline CAR & $146 \mathrm{a}$ & $76.4 \mathrm{a}$ & $53.6 \mathrm{a}$ & $2.92 \mathrm{~d}$ & $11.9 \mathrm{~b}$ & $0.92 \mathrm{~b}$ & $13.1 \mathrm{ab}$ \\
\hline TAI & 132 bcde & $68.5 \mathrm{bc}$ & $53.4 \mathrm{ab}$ & $3.00 \mathrm{~cd}$ & $11.0 \mathrm{~cd}$ & $0.91 \mathrm{bc}$ & $12.4 \mathrm{~b}$ \\
\hline RLE & $141 \mathrm{ab}$ & $71.0 \mathrm{ab}$ & $51.6 \mathrm{~b}$ & $3.14 \mathrm{bc}$ & $10.6 \mathrm{~d}$ & $0.82 \mathrm{~d}$ & $13.5 \mathrm{a}$ \\
\hline VOL & $136 \mathrm{bcd}$ & $71.2 \mathrm{ab}$ & $53.8 \mathrm{a}$ & $3.06 \mathrm{bcd}$ & $10.7 \mathrm{~cd}$ & $0.82 \mathrm{~d}$ & $13.5 \mathrm{a}$ \\
\hline MAC & 130 cde & $66.9 \mathrm{bc}$ & $52.6 \mathrm{ab}$ & $3.20 \mathrm{ab}$ & $10.9 \mathrm{~cd}$ & $0.90 \mathrm{bc}$ & $12.4 \mathrm{~b}$ \\
\hline $\mathrm{BAT}$ & $126 \mathrm{de}$ & $64.5 \mathrm{c}$ & $52.9 \mathrm{ab}$ & $3.03 \mathrm{~cd}$ & $11.7 \mathrm{~b}$ & $0.93 \mathrm{~b}$ & $12.8 \mathrm{ab}$ \\
\hline SAV & $124 \mathrm{e}$ & $64.3 \mathrm{c}$ & $53.1 \mathrm{ab}$ & $3.02 \mathrm{~cd}$ & $12.4 \mathrm{a}$ & $1.02 \mathrm{a}$ & $12.4 \mathrm{~b}$ \\
\hline $\mathrm{ICH}$ & $138 a b c$ & $71.2 \mathrm{ab}$ & $53.2 \mathrm{ab}$ & $3.02 \mathrm{~cd}$ & $11.8 \mathrm{~b}$ & $0.91 \mathrm{bc}$ & $13.1 \mathrm{ab}$ \\
\hline PAL & 133 bcde & $67.0 \mathrm{bc}$ & $51.6 \mathrm{~b}$ & $3.30 \mathrm{a}$ & $11.1 \mathrm{c}$ & $0.86 \mathrm{~cd}$ & $13.1 \mathrm{ab}$ \\
\hline
\end{tabular}

${ }^{2}$ Each value is the mean of 7 years with four two-tree replications per year. Mean separation within columns by Duncan's multiple range test, $P=0.05$ :

${ }^{\mathrm{y}}$ Abbreviations: $\mathrm{YUM}=$ Yuma citrange; $\mathrm{CAR}=$ Carrizo citrange; TAI = C. taiwanica; $\mathrm{RLE}=$ rough lemon; VOL = Volkamer lemon; $\mathrm{MAC}=$ C. macrophylla $; \mathrm{BAT}=$ Batangas mandarin; $\mathrm{SAV}=$ Savage citrange; $\mathrm{ICH}=$ Ichang pummelo; PAL $=$ Palestine sweet lime.

lationship between trees on these two rootstock in 1974 (Table 1) and 1980 (10 years after planting) (data not shown). But, trees on both of these rootstock had similar trunk cross-sectional areas and canopy volumes 18 years after planting (Table 1). In general, trees on high-yielding rootstock had larger canopy volumes and trunk cross-sectional areas than those on lowyielding rootstock (Table 1).

Fruit weight, juice content, and peel thickness. 'Orlando' tangelo fruit from trees on Carrizo citrange and rough lemon were heavier and contained more juice than those from trees on macrophylla, Batangas mandarin, and Savage citrange (Table 2). However, percent juice in' the fruit from trees on rough lemon was significantly lower than those on Carrizo citrange and similar to fruit from trees on Batangas mandarin and Savage citrange. Percent juice is highly correlated to total juice per fruit and peel thickness, and fruit from trees on rough lemon had a thicker peel than those on Carrizo citrange, Batangas mandarin, and Savage citrange (Table 2). Our results differ from a 2-year study by Hutchison and Hearn (1977) in Florida where 'Orlando' tangelo fruit on rough lemon were larger than those of Carrizo citrange, while percent juice content of fruit from these rootstock was similar.

The peel of fruit from trees on macrophylla and Palestine sweet lime was significantly thicker than on Carrizo citrange, Batangas mandarin, Ichang pummelo, and Savage citrange (Table 2).

Soluble solids and acid concentration and solids: acid ratio. Fruit from trees on Savage citrange had the highest TSS and TA (Table 2). This agrees with our previous report for grapefruit on 12 rootstock grown under a similar climatic condition (Fallahi et al., 1989), which could be due to a higher leaf : fruit ratio in the trees on Savage rootstock. Fruit from trees on Carrizo citrange had a higher TSS and TA than those on rough lemon (Table 2), concurring with earlier reports (Hutchison and Hearn, 1977; Krezdorn, 1977; Krezdorn and Phillips, 1970). The TSS : TA ratios in the fruit from trees on Carrizo and rough lemon were similar, which differs from studies by Krezdorn and Phillips (1970) and Krezdorn (1977), who reported a higher TSS : TA ratio in the fruit from trees on rough lemon than on Carrizo citrange in Florida. TSS and TA in the fruit from trees on Carrizo citrange, Yuma citrange, Batangas mandarin, and Ichang pummelo were intermediate, while those on rough lemon, Volkamer lemon, and Palestine sweet lime were low (Table 2). Fruit from trees on rough lemon, Volkamer lemon, and Palestine sweet lime, in spite of their low TSS, had high TSS : TA ratios due to their low acid content (Table 2).
Overall, Carrizo citrange is a suitable rootstock for 'Orlando' tangelo in Arizona. It gives high yield, large fruit, high juice content, and thin peel. The reason for the good performance (yield, growth, and overall quality) of 'Orlando' tangelo trees on citrange rootstock, particularly Carrizo, under the conditions of this experiment is not clear. Leaves of 'Orlando' tangelo trees on all citranges, particularly Carrizo, had lower $\mathrm{N}$ but higher $\mathrm{Ca}$ than those on other rootstock (data not shown). Volkamer lemon, rough lemon, Yuma citrange, and Taiwanica are also very productive, but fruit quality is poor to intermediate. Fruit from trees on rough lemon and Volkamer lemon had high TSS : TA ratios in spite of their low TSS (Table 2). 'Orlando' tangelo trees on macrophylla rootstock decline at early ages; thus, macrophylla is not advisable for 'Orlando' tangelo. However, if 'Orlando' trees are to be budded on macrophylla because of precocity, trees could be planted at a closer spacing than $7 \times 7 \mathrm{~m}$ because trees on macrophylla produce small canopies (Table 1). Savage citrange is a good rootstock if high TSS and TA are the primary objective of 'Orlando' tangelo production. However, 'Orlando' tangelo trees on Savage citrange produced small fruit. Also trees on both Savage citrange and Ichang pummelo had low per-tree production. Therefore, Savage citrange, and Ichang pummelo cannot be recommended at $7 \times 7-\mathrm{m}$ spacing for 'Orlando' tangelo, but they could be planted at a higher density because of their small canopy volume. 'Orlando' fruit on these rootstock had relatively good quality and/or good fruit size. Trees on Palestine sweet lime showed severe signs of decline, and those on Batangas mandarin had neither high yield nor good quality and cannot be recommended for 'Orlando' tangelo under conditions similar to those of this experiment.

\section{Literature Cited}

Arizona Agricultural Statistics. 1988. Arizona Agr. Stat. Serv., Phoenix. Bul. S-24:64.

Castle, W.C. 1980. Citrus rootstock for tree size control and higher density plantings in Florida. Proc. Fla. State Hort. Soc. 93:24-27.

Castle, W.C. 1987. Citrus rootstock, p. 361-399. In: R.C. Rom and R.F. Carlson (eds.). Rootstock for fruit crops. Wiley, New York.

Castle, W.C. and R.L. Phillips. 1977. Potential dwarfing rootstock for Florida citrus. Proc. Intl. Soc. Citriculture 2:558-561.

Cooper, W.C. and J.S. Bruce. 1950. Quality of red grapefruit on oldline grapefruit varieties on xyloporosis exocortis tolerant rootstock. J. Rio Grande Valley Hort. Soc. 14:66--76. 
Fallahi, E., J.W. Moon, Jr., and D.R. Rodney. 1989. Yield and quality of 'Redblush' grapefruit on twelve rootstock. J. Amer. Soc. Hort. Sci. 114(2):187-190.

Fallahi, E., D.R. Rodney, and Z. Mousavi. 1990. Growth, yield and fruit quality of eight lemon cultivars in Arizona. J. Amer. Soc. Hort. Sci. 115(1):6-8.

Gardner, F.E. and G.E. Horanic. 1966, Growth, yield and fruit quality of Marsh grapefruit on various rootstock on the Florida East (CoastA preliminary report. Fla. State Hort. Soc. Proc. 79:109-114.

Hilgeman, R. H., D.R. Rodney, J.A. Dunlap, and T.A. Hales. 1966. Rootstock evaluation for lemons on two soil types in Arizona. Proc. Amer. Soc. Hort. Sci. 80:280-290.

Hutchison; D.J. and C.J. Heam. 1977. The performance of 'Nova' and 'Orlando' tangelos on 10 rootstock Proc. Fla. State Hort. Soc. 9:4749.

Krezdorn, A.H. 1977. Influence of rootstock on mandarin cultivars. Proc. Intl. Soc. Citriculture 2:513-518.

Krezdorn, A.H. and W.J. Phillips. 1970. The influence of rootstock on tree growth, fruiting and fruit quality of 'Orlando' tangelos. Proc. Fla. State Hort. Soc. 83:110-116.

Rouse, R.E. and N.P. Maxwell. 1979. Performance of mature nucellar
'Redblush' grapefruit on 22 rootstock in Texas. J. Amer. Soc. Hort. Sci. 104:449451.

Turrell, F.M. 1961. Growth and photosynthesis area of citrus. Bet. Gaz. 122:284-298.

Wutscher, H.K. 1977. The influence of rootstock on yield and quality of red grapefruit in Texas. Proc. Intl. Soc. Citriculture 2:526-529.

Wutscher, H.K. 1979. Citrus rootstock. Hort. Rev. 1:237-269.

Wutscher, H.K. and D. Dube. 1977. Performance of young nucellar grapefruit on 20 rootstock. J. Amer. Soc. Hort. Sci. 102(3):267-270.

Wutscher, H.K. and A.V. Shun. 1972. Performance of 13 citrus cultivars as rootstock for grapefruit. J. Amer. Soc. Hort Sci. 97(6):778781.

Wutscher, H.K. and A.V. Shun. 1973. The performance of 'Valencia' orange on 16 rootstock in South Texas. Proc. Trop. Reg. Amer. Soc. Hort. Sci. 17:66-73.

Wutscher, H.K. and A.V. Shull 1975. Yield, fruit quality, growth, and leaf nutrient levels of 14 year old grapefruit, Citrus paradisi Mac., trees on 21 rootstock. J. Amer. Soc. Hort Sci.100(3):290-294.

Wutscher, H.K. and A.V. Shun. 1976. Performance of 'Orlando' tangelo on 16 rootstock. J. Amer. Soc. Hort Sci. 101:88-91. 